\title{
Stem Volume Equation and Tree Growth For Rubber Trees in Cambodia
}

\author{
Kakada Khun $^{* 1}$, Nobuya Mizoue ${ }^{* 2}$, Shigejiro Yoshida*2 and Takuhiko Murakami*2,*3
}

\begin{abstract}
Rubber trees (Hevea brasiliensis) in Cambodia are important sources for not only natural rubber but also wood products. This study was conducted to set up stem volume equations to estimate the stand volume and the volume increment for rubber trees in Cambodia. Krek Rubber Plantation located in Kompong Cham Province was selected for study area. Sixty trees of the clone PR107 at the age of 36, 44, 45 and 46 were felled and cut into segments of one meter long to formulate the volume equation. The DBH and total height of 450 standing trees (15 plots) at different ages (6-10 and 36-48) were measured to estimate volume per hectare and the mean annual increment (MAI). This study revealed that the volume equation for standing rubber trees clone PR107 is $V=0.00018381 D^{2.23961} H^{0.15334}$ or $V$ $=0.00024884 D^{2.29535}$ where $V$ is the over bark volume $\left(\mathrm{m}^{3}\right), D$ is diameter at breast height $(\mathrm{cm}), H$ is total height (m). Using the two-variable equation, rubber wood volume at the rotation length of 25-30 years was estimated at about $240-270 \mathrm{~m}^{3} \mathrm{ha}^{-1}$ with the MAI of $9.33 \mathrm{~m}^{3} \mathrm{ha}^{-1} \mathrm{yr}^{-1}$.
\end{abstract}

Keywords: rubber trees, volume equation, stem volume, tree growth, mean annual increment (MAI)

\section{INTRODUCTION}

Rubber tree (Hevea brasiliensis), which is indigenous to the Amazon basin and was named as "white gold" in the earlier twentieth century, has been playing a significant role in sustaining socio-economic base of many countries in the world, especially in South East Asia accounting for about $80 \%$ of the total areas under rubber worldwide. The exploitation of rubber trees focused solely on their resin called "Latex" during 25 to 30 years of their life expectancy before being cut down and replanted. Many researchers paid their attention to how to manage the rubber plantations to maximize latex through breeding, cloning or fertilizer application (SHORROcK

Corresponding author: Nobuya Mizoue

${ }^{* 1}$ Department of Forests and Forest Products Sciences, Graduate School of Bioresource and Bioenvironmental Sciences, Kyushu University, Fukuoka 812-8581, Japan

Present address: General Directorate of Rubber Plantations, Phnom Penh, Cambodia

${ }^{* 2}$ Department of Forests and Forest Products Sciences, Faculty of Agriculture, Kyushu University, Fukuoka 812-8581, Japan

${ }^{* 3}$ Present address: Faculty of Agriculture, Niigata University, Niigata 950-2181, Japan et al., 1965; COluIng and SOWCHING, 1967; NARAYANAN and Hochai, 1973; NARAYANAN et al., 1973; NGA and Subramaniam, 1974; SAMSUDDIN et al., 1987). In the past decades, some authors started to pay much attention to rubber wood (Westgarth and Buttery, 1965; Templeton, 1969; Mainstone, 1970; Senghuat, 1981; Sim, 1989; NaJiB and Othman, 1996) and from the 1980s, there has been growing interest in maximizing the utilization of rubber woods. Further, due to their potentials as a source of raw materials, much attention is being focused on rubber wood as a source of sawn timber to supplement the existing supply (WANRAZALI et al., 1983). However, there has been very few information on volume equation and mean annual increment (MAI) of rubber trees. To our knowledge, there is only one paper on volume equation developed by WANRAZALr et al. (1983) as rubber wood, in the past, was burnt on the spot or mainly used as wood fuel for locomotive engines, brick burning or latex curing (FAO, 2001b).

In Cambodia, the first rubber plantation was established by a French national Mr. Boulliard in 1910 in Prey Nup district, Kompot province, but the establishment of grand rubber plantations for industrial purpose started in 1920 (Tichiт, 1981). Since then the share of rubber sector in national economy become more and more vital. In 1964, the exportation of rubber productions increased by $24 \%$ of agricultural share in GDP, ranked second after rice production (MAFF, 1965), and in 2004 rubber productions contributed to $4 \%$ of $33 \%$ of agricultural contribution to GDP, ranked second after forest productions (MAFF, 2004). Now around sixty 
thousands hectares have been occupied by rubber plantations throughout the country. In mid 1990s as the trend of rubber wood processing from foreign countries started in Cambodia, the central government set up a ten-year program of cutting and replanting of rubber trees. Thousands of hectares of old rubber trees per year were felled and sold to rubber wood processing companies. Unfortunately, little information is available concerning either individual tree volumes or mean annual increment (MAI). Therefore, there is an urgent need to develop volume equation and to know the growth rate of rubber trees planted in Cambodia for a better future management.

The objectives of this study were to set up volume equations and to estimate stand volume and the mean annual increment per hectare for the rubber trees in Cambodia. In this study, we investigated the clone PR107, one of the most common clones in Cambodia.

\section{STUDY SITE}

The study area is in Krek Rubber Plantation $\left(105^{\circ} 53\right.$ '38"E$106^{\circ} 00^{\prime} 18^{\prime \prime} \mathrm{E}$ and $\left.11^{\circ} 46^{\prime} 23^{\prime \prime} \mathrm{N}-11^{\circ} 53^{\prime} 27^{\prime \prime} \mathrm{N}\right)$, located in Kompong Cham Province around $190 \mathrm{~km}$ from Phnom Penh, the capital city (Fig. 1). Large part of the plantation's soil is red basaltic with the average of $\mathrm{PH}=4.57$ (RRIC, 1968) and the climate is tropical with a bi-annual change of monsoonal systems, the rainy season (May-October) and the dry season (NovemberApril). Mean annual rainfall and temperature have been $1,700 \mathrm{~mm}$ and $28^{\circ} \mathrm{C}$ respectively. The total areas under rubber from one to 54 years old in 2005 were 3899.63 ha. Due to the civil war during 1970-1990, there are no stands of the age from 15 to 35 years old in 2005 .

\section{MATERIALS AND METHODS}

To make the volume equations, we used 60 trees from 4 stands at different ages 36, 44, 45 and 46 (Table 1). Before felling, we measured total height and diameter at breast height (DBH at 1.3m) using Vertex III (Haglof, Finland) and diameter tapes, respectively. Then we felled them down, cut into segments of one meter in length (up to $10 \mathrm{~cm}$ diameter of branches), measured and recorded diameters of both end sides of each segment. Volumes per segment and per tree were calculated by SMALIAN's formula as follows;

$$
V_{s}=\frac{A_{1}+A_{2}}{2} L
$$

where $V_{s}$ is segment volume $\left(\mathrm{m}^{3}\right), A_{1}$ and $A_{2}$ are cross sectional areas of both end sides of segment $\left(\mathrm{m}^{2}\right)$, and $L$ is length of segment $(\mathrm{m})$. We developed the widely used volume equations; one variable formula (2) and SchUMACHER-HaLl's formula (3), and the coefficients were estimated by standard

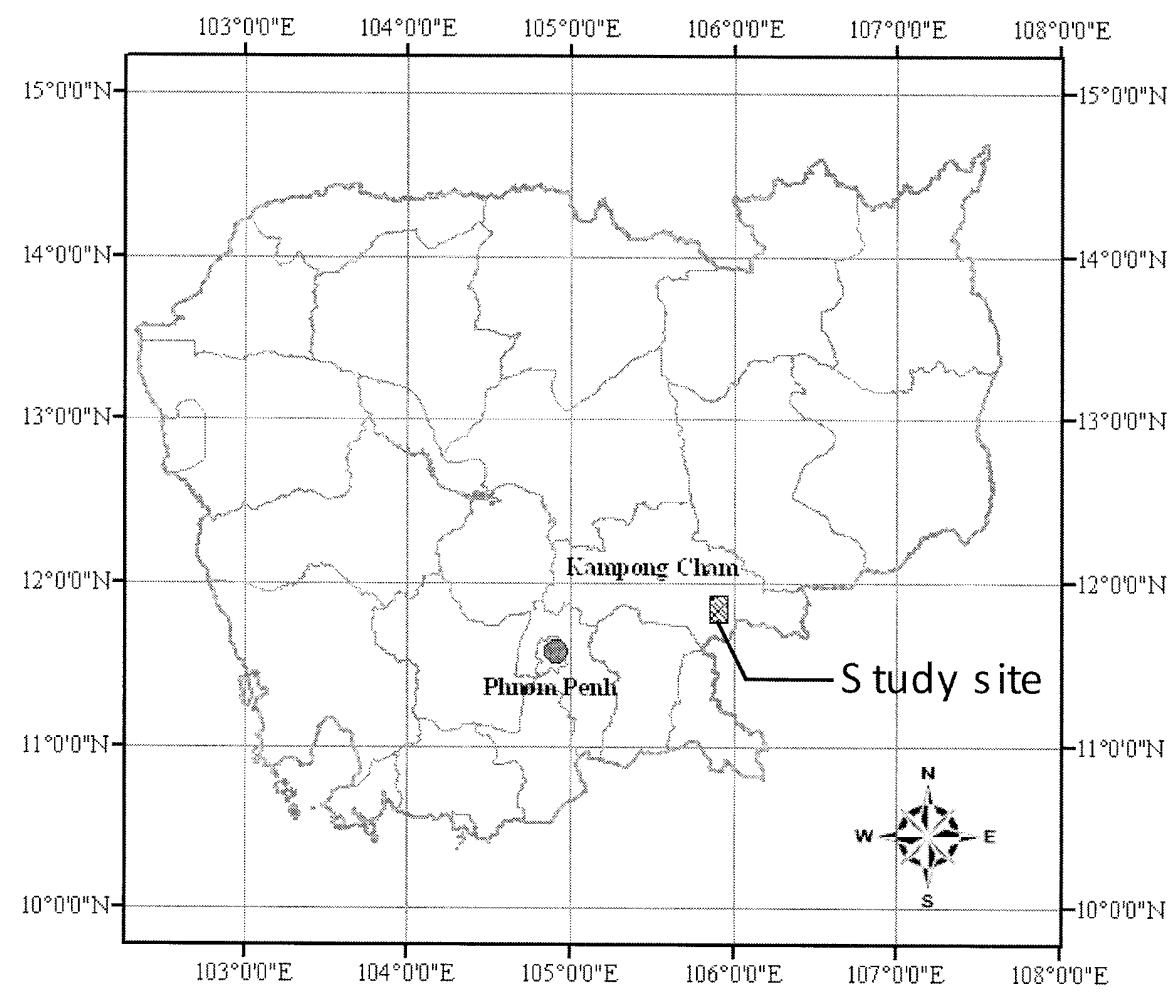

Fig. 1 Location of study site 
linear regression methods by applying a logarithmic transformation, the formulae (4) and (5), using the statistic software R;

$$
\begin{aligned}
& V=\mathrm{a}_{1} D^{\mathrm{b} 1}, \\
& V=\mathrm{a}_{2} D^{\mathrm{b} 2} H^{\mathrm{c} 2} . \\
& \log V=\log \mathrm{a}_{1}+\mathrm{b}_{1} \log D, \\
& \log V=\log \mathrm{a}_{2}+\mathrm{b}_{2} \log D+\mathrm{c}_{2} \log H,
\end{aligned}
$$

where $V$ is total volume, $D$ is dbh $(\mathrm{cm}), H$ is total height (m), and $\mathrm{a}_{1}, \mathrm{~b}_{1}, \mathrm{a}_{2}, \mathrm{~b}_{2}, \mathrm{c}_{2}$, are constants.

In order to estimate stand volume and its increment, we established 15 sample plots at different ages (6-10 and 36-48). Each sample plot included three planting lines; each has 10 trees as shown in Fig. 2. The planting points were designed regularly equidistant from one stem to one stem and from one line to another line. However, in the sample plots some trees

\begin{tabular}{|c|c|c|c|c|c|c|c|c|c|c|}
\hline \multirow{2}{*}{$\begin{array}{r}\text { Ages } \\
\text { in } 2005 \\
\end{array}$} & \multirow{2}{*}{$\begin{array}{l}\text { Plot Areas } \\
\qquad\left(\mathrm{m}^{2}\right)\end{array}$} & \multirow{2}{*}{$\begin{array}{c}\text { No. trees } \\
\text { per ha }\end{array}$} & \multicolumn{3}{|c|}{ DBH $(\mathrm{cm})$} & \multicolumn{3}{|c|}{ Total Height (m) } & \multirow{2}{*}{$\begin{array}{r}\text { Volume } \\
\mathrm{m}^{3} / \mathrm{ha}\end{array}$} & \multirow{2}{*}{$\begin{array}{c}\text { MAI } \\
\mathrm{m}^{3} / \mathrm{ha} / \text { year }\end{array}$} \\
\hline & & & Max & Min & Mean & $\operatorname{Max}$ & Min & Mean & & \\
\hline 6 & 538 & 558 & 19.2 & 15.2 & 14.3 & 9 & 8.2 & 12.8 & 61 & 10.10 \\
\hline 8 & 521 & 575 & 24.0 & 9.9 & 17.1 & 18.8 & 10.5 & 15.5 & 98 & 12.19 \\
\hline 9 & 597 & 502 & 22.7 & 9.0 & 16.0 & 19.6 & 9.0 & 15.2 & 74 & 8.22 \\
\hline 10 & 594 & 505 & 23.7 & 10.9 & 16.3 & 18.1 & 9.0 & 14.8 & 78 & 7.78 \\
\hline 37 & 1,049 & 286 & 73.0 & 19.7 & 39.1 & 37.8 & 15.7 & 26.6 & 366 & 9.88 \\
\hline 38 & 783 & 383 & 50.5 & 17.4 & 35.2 & 39.6 & 16.9 & 27.7 & 374 & 9.85 \\
\hline 39 & 620 & 484 & 52.7 & 19.8 & 33.6 & 41.5 & 14.1 & 22.9 & 398 & 10.20 \\
\hline 40 & 812 & 369 & 41.7 & 20.7 & 34.4 & 39.6 & 23.0 & 30.6 & 331 & 8.26 \\
\hline 41 & 1,120 & 268 & 61.1 & 49.5 & 38.8 & 19.2 & 14.6 & 26.3 & 336 & 8.19 \\
\hline 42 & 817 & 367 & 50.8 & 17.2 & 35.2 & 41.7 & 14.8 & 27.9 & 356 & 8.48 \\
\hline 44 & 945 & 318 & 62.3 & 17.4 & 41.5 & 50.4 & 15.1 & 31.5 & 455 & 10.33 \\
\hline 45 & 699 & 429 & 50.5 & 20.8 & 37.2 & 37.2 & 15.6 & 25.6 & 448 & 9.96 \\
\hline 46 & 971 & 309 & 54.6 & 24.0 & 40.6 & 42.2 & 17.6 & 31.9 & 412 & 8.95 \\
\hline 47 & 851 & 352 & 52.0 & 25.1 & 38.1 & 42.5 & 16.4 & 31.6 & 406 & 8.64 \\
\hline 48 & 740 & 405 & 60.2 & 19.9 & 37.5 & 50.1 & 17.0 & 33.4 & 473 & 9.86 \\
\hline
\end{tabular}

Table 1 Summary of data for volume equation

\begin{tabular}{|c|c|c|c|c|c|c|c|c|c|c|c|c|c|c|}
\hline f & 2 & ${ }_{0}^{3}$ & ${ }_{0}^{4}$ & $\begin{array}{l}5 \\
0\end{array}$ & $\stackrel{6}{6}$ & 0 & $\stackrel{8}{0}$ & $\stackrel{9}{0}$ & $\begin{array}{l}10 \\
0\end{array}$ & & & & & \\
\hline \multirow[t]{2}{*}{$\begin{array}{l}11 \\
0\end{array}$} & $\begin{array}{l}12 \\
0\end{array}$ & $\times$ & 13 & 14 & $x$ & $x$ & 15 & 16 & $x$ & $x$ & 17 & 18 & $\begin{array}{l}19 \\
0\end{array}$ & $\begin{array}{l}20 \\
0\end{array}$ \\
\hline & ${ }^{21}$ & 22 & 23 & $x$ & 24 & 25 & $x$ & 26 & $\times$ & 27 & $x$ & 28 & 29 & $\begin{array}{l}30 \\
0\end{array}$ \\
\hline
\end{tabular}

\begin{tabular}{rrrrr}
\hline $\begin{array}{l}\text { Stands } \\
\text { Age (years) }\end{array}$ & A & B & C & D \\
\cline { 1 - 4 } DBH (cm) & 36 & 44 & 45 & 46 \\
mean & 34.5 & 44.8 & 42.4 & 39.8 \\
min & 26.0 & 28.0 & 29.8 & 26.5 \\
max & 41.0 & 62.0 & 56.4 & 52.0 \\
Total Height (m) & & & & \\
mean & 23.5 & 32.0 & 28.0 & 27.8 \\
min & 16.2 & 25.3 & 18.4 & 16.9 \\
max & 25.3 & 42.1 & 35.9 & 47.3 \\
Stem volume (m) & estimated by Smalian's formular & \\
mean & 0.90 & 1.84 & 1.29 & 1.22 \\
min & 0.25 & 0.60 & 0.65 & 0.41 \\
max & 1.37 & 3.41 & 2.21 & 2.30 \\
\hline
\end{tabular}

Table 2 Primary data of 450 standing trees in 15 sample Plots

Fig. 2 Lay out of Sample Plots

The circle and cross symbols indicate living and dead or removed trees, respectively. 
were dead or removed out and therefore the area of each plot was calculated in the form of three rectangles while each length of every 10 trees was made by the direct measurements, and the width was based on the records of the interval of planting lines which varied from $6 \mathrm{~m}, 7 \mathrm{~m}$ to $8 \mathrm{~m}$. The areas of sample plots varied from $538 \mathrm{~m}^{2}-971 \mathrm{~m}^{2}$ (Table 2). DBH and total height of 450 standing trees in 15 sample plots were measured by the diameter tapes and Vertex III tools, respectively. Volume per hectare in each sample plot was calculated by the more reliable set up volume equation.

\section{RESULTS AND DISCUSSION}

Volume Equations

Table 1 shows summary of data used for developing volume equations for 4 stands. The range of data is $20-62 \mathrm{~cm}$ for DBH, $16.7-47.0 \mathrm{~m}$ for total height, and 0.25 to $3.41 \mathrm{~m}^{3}$ for stem volume. Fig. 3 showed the relationship between $\log V$ and $\log D$, and the one variable formula was

$$
\begin{aligned}
& \log V=-3.6041+2.2953 \log D\left(R^{2}=0.9233, N=60\right), \\
& \text { or } V=0.00024884 D^{2.2953} \text {. }
\end{aligned}
$$

\section{SCHUMACHER-HALL's formula was}

$\log V=-3.73563+2.23961 \log D+0.15334 \log H$, $\left(R^{2}=0.9245, N=60\right)$,

$$
\text { or } V=0.00018381 D^{2.23961} H^{0.15334} \text {. }
$$

Statistically, the results of the two formulae found no much difference $\left(R^{2}=0.9233, R^{2}=0.9245\right)$, and this may be due to high correlation between $D$ and $H$. This result indicates that the one variable formula using only $\mathrm{DBH}$ is applicable for the studied clone.

To check the applicability of the volume equations

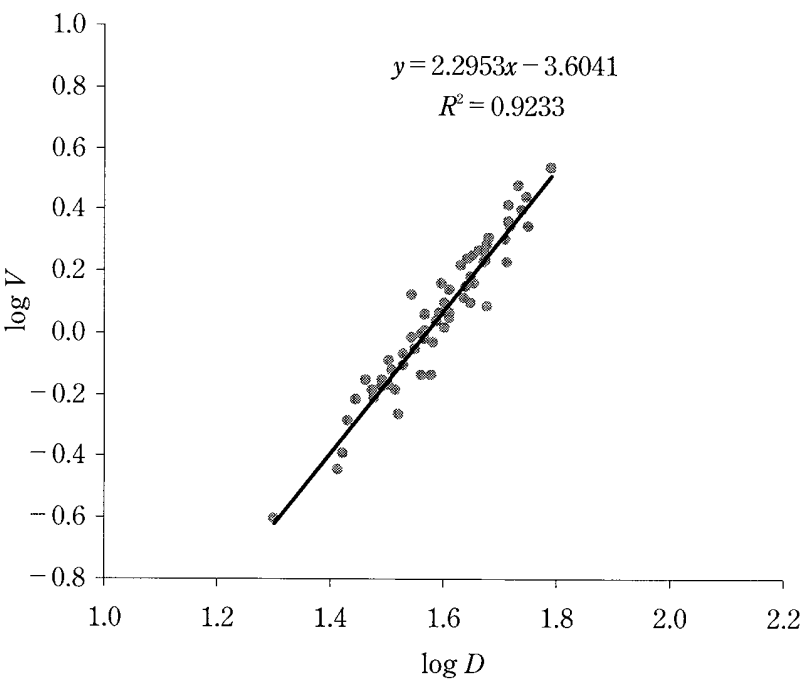

Fig. 3 Volume of 60 felled trees based on DBH

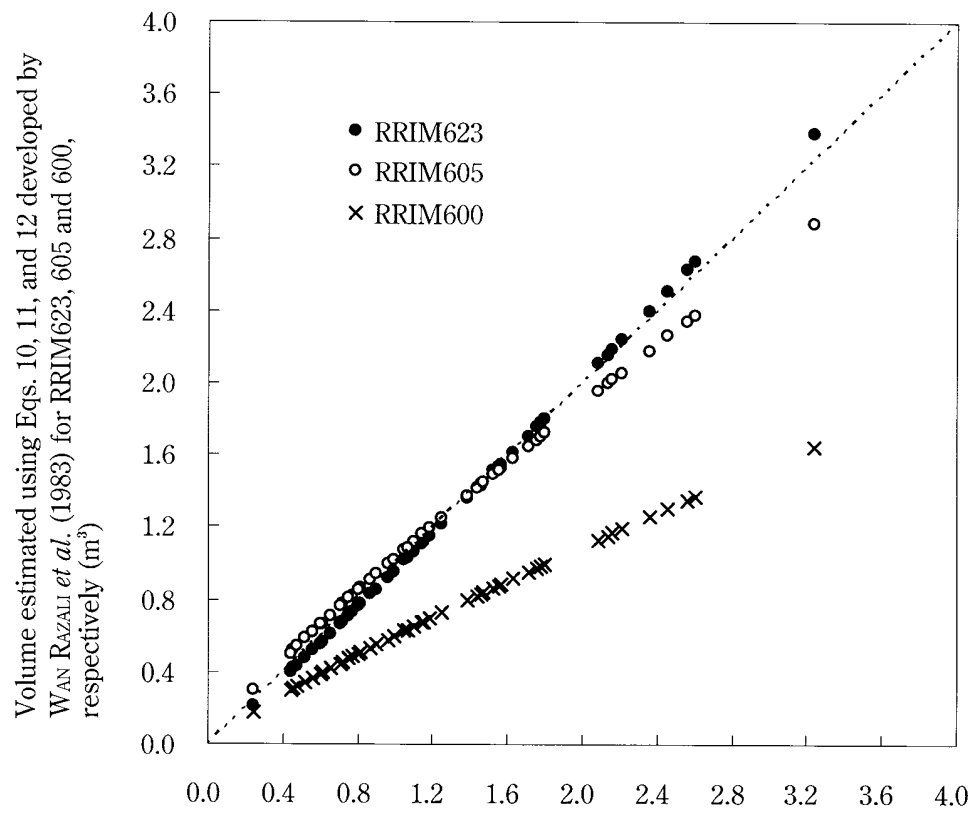

Volume estimated using Eq. 6 developed in this study for PR107 $\left(\mathrm{m}^{3}\right)$

Fig. 4 Comparison of wood volume for the 60 sample trees estimated using the one-variable equations developed for the clone PR107 in this study (Eq. 6) and by WAN RAZALI et al. (1983) for the three clones; RRIM623 (Eq.10), RRIM605 (Eq.11) and RRIM600 (Eq. 12)

Note: The broken line indicates 1:1. 
developed in this study to other clones, we compared wood volume for the 60 sample trees estimated using the onevariable equations developed for the clone PR107 in this study (Eq.6) and by Wanrazali et al., (1983) for the three clones; RRIM623 (Eq.10), RRIM605 (Eq.11) and RRIM600 (Eq. 12) as follows;

$$
\begin{aligned}
\log V=2.4627 \log D-3.88570656 \\
\quad\left(\text { for RRIM623, } R^{2}=0.4280\right), \\
\log V=2.01461 \log D-3.151701113 \\
\quad\left(\text { for RRIM605, } R^{2}=0.5754\right), \\
\log V=1.97473 \log D-3.321792547 \\
\left.\quad \text { (for RRIM600, } R^{2}=0.5148\right) .
\end{aligned}
$$

As shown in Fig. 4, the relationship of the estimated volume between Eq.10 for RRIM623 and Eq. 6 for PR107 is very close to the $1: 1$ line, indicating that the volume equation developed in this study can be applied not only for PR107 but also for RRIM623. However, our PR107-equation tends to slightly underestimate and overestimate the volume from the RRIM605 equation for trees with smaller and larger than about $1.2 \mathrm{~m}^{3}$, respectively, while consistently overestimating the volume estimated from the RRIM600 over all range of tree size (Fig. 4). Due to the existence of more different clones of rubber trees (about 25 clones), we need more comprehensive and intensive research on the volume equations as in AKINDELE and LEMAY (2006) who classified the volume equations for 77 common timber species in the tropical rain forests into 5 species groups.

\section{Tree Growth}

Table 2 shows summary for 15 sample plots. Fig. $5 \mathrm{a}, 5 \mathrm{~b}$ and 6 indicate the changes in total height, DBH and stand volume in relation to stand age, respectively. The ranges of mean values are 14.3 to $41.6 \mathrm{~cm}$ for DBH and 12.8 to $33.4 \mathrm{~m}$ for total height. The stand volume per hectare is from 60.6 to $473.5 \mathrm{~m}^{3}$. Due to no planting during civil war (1970-1990), we can not exactly predict tree size at the age $25-30$ years old that is common rotation age. To get rough information at the age 25-30, linear regression lines are indicated in the Fig.5 and 6 .

There were not large differences between different stands in the mean annual increment (MAI), which is stand volume at a given age divided by the age (Table 2 ). The average MAI of all plots was $9.33 \mathrm{~m}^{3} / \mathrm{ha} / \mathrm{yr}$, which was larger than the value of $7 \mathrm{~m}^{3} / \mathrm{ha} / \mathrm{yr}$ for Indonesia, Malaysia, Thailand and Vietnam reported in the FAO working paper (FAO, 2005). It was described that stand volume of rubber wood is about $250 \mathrm{~m}^{3}$ in Thailand (CHANTUMA et al., 2002) and $207.9 \mathrm{~m}^{3}$ in Malaysia (Suratman et al., 2004) at 25-30 year old trees that are common rotation age. Based on the regression line shown in Fig. 6 of our results, the stand volume was estimated to be $240 \mathrm{~m}^{3}-270 \mathrm{~m}^{3}$ at $25-30$ years old trees, indicating that there are not large differences among those three countries. However, stand volume per hectare depends upon numerous factors such as clones, sites, and management system (FAO, 2001a), so we need more investigation for each clone and site covering wide range of age classes.

Is the growth potential of rubber tree higher than other plantation tree species in tropical forests? The mean annual increment (MAI) of volume/ha for rubber trees in Cambodia was also not remarkably lower if compared to teak plantations (Tectona grandis) - a world's premier hardwood timber planted mostly in tropical zones. MAI of teak plantations in Indonesia and Myanmar with 50 year rotation age were found $13.8 \mathrm{~m}^{3} \mathrm{ha}^{-1} \mathrm{y}^{-1}$ and $8.7 \mathrm{~m}^{3} \mathrm{ha}^{-1} \mathrm{y}^{-1}$ (PANDEY and BROWN, 2000) respectively while Acacia mangium has $24 \mathrm{~m}^{3} \mathrm{ha}^{-1} \mathrm{y}^{-1}$ of the MAI in Malaysia (FAO, 2005). According to this 2005 FAO working paper, the MAI of Eucaltyptus robusta is $21 \mathrm{~m}^{3} \mathrm{ha}^{-1} \mathrm{y}^{-1}$ in Malaysia, India and Papua New Guinea, and Casuarina equisetifolia in Asia has $7-10 \mathrm{~m}^{3} \mathrm{ha}^{-1} \mathrm{y}^{-1}$ of the MAI. Based on these references, the growth potential of rubber tree in
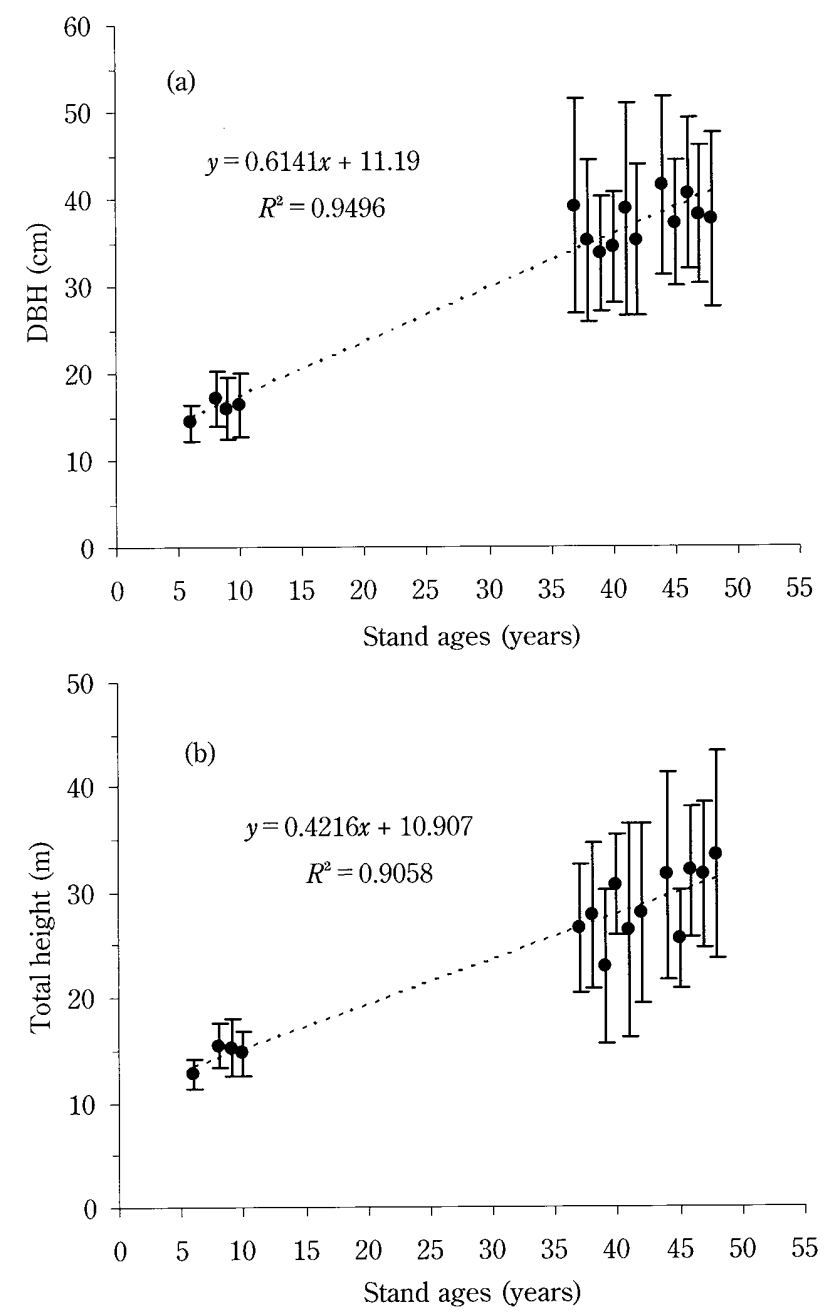

Fig. 5 Relationship between DBH (a), TH (b) and Ages. The dots and error bars indicate mean and standard deviation, respectively. 


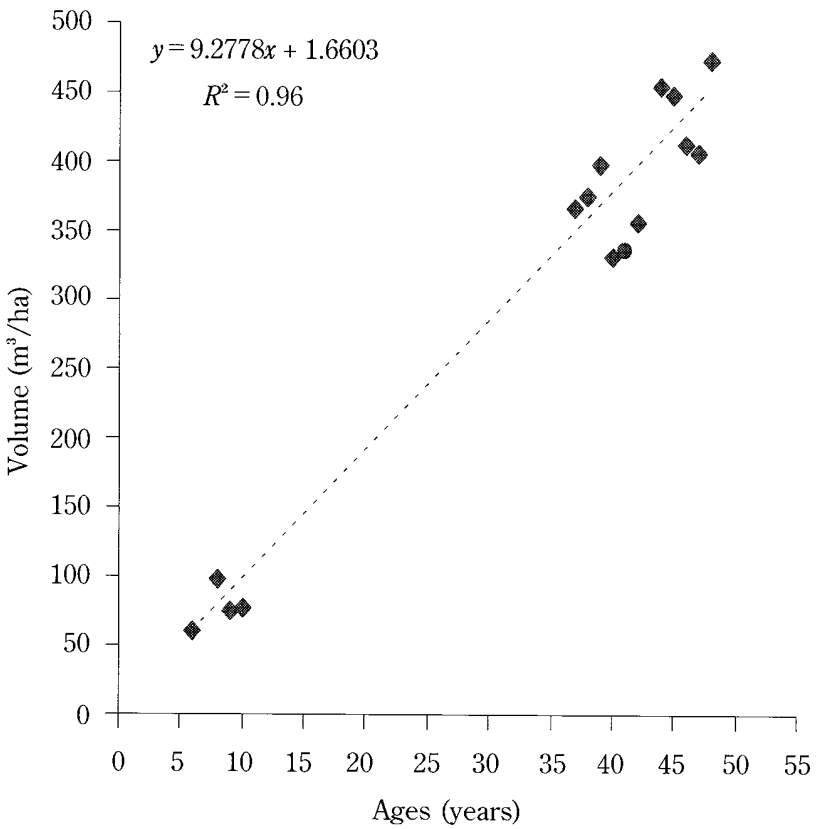

Fig.6 Volume of 15 stands by ages

Cambodia is lower than the fast growing species such as Acacia mangium and Eucaltyptus robusta, but not so large different from the other species.

\section{CONCLUSIONS}

This study is the first trial to develop wood volume equation and growth information of rubber trees in Cambodia, being very essential for better management of rubber forests. Although our samples were lack of the middle ages (15-30 years old) due to internal war, we obtained the following findings;

1) Both of the one - and two - variable volume equations were well-fitted.

2) The developed one-variable equation for the clone PR107 can be used for the clone RRIM623.

3) The MAI was about $9 \mathrm{~m}^{3} \mathrm{ha}^{-1} \mathrm{y}^{-1}$, being smaller than the fast-growing species and similar to other species such as Teak.

4) The stand volume estimated for common rotation ages (25-30 years old) may be about $240-270 \mathrm{~m}^{3} / \mathrm{ha}$, similar to the value reported in Malaysia and Thailand.

However, our result calls for further research to develop volume equations and predict stand growth for other clones in various regions.

\section{ACKNOWLEDGEMENT}

We would like to extend our deep gratitude to His Excellency LY PHALLA, Director General of The General
Directorate of Rubber Plantations, Cambodia, Mr SIEK PISETH, General Director of Krek rubber plantation, Mr TEP Phalla and $\mathrm{Mr}$ Kong SoKChEA, staffs in Krek rubber plantation who supported and helped us by all means for data collection. We also thank Dr SATOShI ITo, Associate Professor of Miyazaki University and Mr TsuYosHI KAJISA, doctor course student of Kyushu University, Japan, for their recommendations and their kind assistance of direct re-measuring the length of all sample plots.

\section{LITERATURE SITED}

Akindele, S.O. and Lemay, V.M., (2006): Development of tree volume equation for common timber species in the tropical rain forest area of Nigeria. For. Ecol. Management: 41-48

Chantuma, A., Chantuma, P., Prommee, P. and Konksile, J., (2002): Cultivation rubber wood productivity in Thailand; Rubber Research Institute of Thailand (unpublished)

Coluin, B. and Sowching, L., (1967): Effect of planting on the growth, yield and economic exploitation of Hevea brasiliensis Part II. The effect on profit. J. Rubb. Res. Inst. Malaysia 20(1): 44-64

FAO, (2001a): Mean annual increment of selected industrial forest plantation species by L Ugalde \& O Perez. Forest Plantation Thematic Papers, Working paper 1. Forest Resources Development Service, Forest Resources Division. FAO, Rome (unpublished)

FAO, (2001b): Non-forest tree plantations. Report based on the work of W. killmann. Forest Plantation Thematic Papers, Working paper 6. Forest Resources Development Service, forest Resources Division. FAO, Rome (unpublished)

FAO, (2005): Global Planted Forest Thematic, Supplement to Forest Resources Assessment 2005, Guidelines for National Reporting Tables for Planted Forests, by Del Lungo, A. andCarle, J.B. Planted Forests and Trees Working Papers, Working Paper 35E. Forest Resources Development Service, Forest Resources Division. FAO, Rome (unpublished)

GDRP, (2004): Cambodian Natural Rubber Bulletin 44 General Directorate of Rubber Plantations, Cambodia (in Khmer)

KRP, (2005): Statistic of mature and immature rubber trees in 2005, Krek Rubber Plantation, Cambodia (in Khmer)

MAFF, (1965): Annual Report of agricultural productions, 1964. Ministry of Agriculture, Forestry and Fisheries, Cambodia (in Khmer)

MAFF, (2004): Annual report of agricultural productions, 2004. Ministry of Agriculture, Forestry and Fisheries, Cambodia (in Khmer)

Mainstone, B.J., (1970): Plant density- early effect on growth pattern of Hevea brasiliensis. J. Rubb. Res. Inst. Malaysia 23(1): 56-67

NAJIB, L. B.A. and OTHMAN, R.B., (1996): Rubber plantations as a timber resource, The Planter 72: 483-500

Narayanan, R., Gomez, J. B. and Chen, K. T., (1973): Some structural factors affecting the productivity of Hevea brasiliensis II. Correlation Studies between structural factors and yields. J. Rubb. Res. Inst. Malaysia 23(4): 285-297

Narayanan, R. and Hochai, Y., (1970): Yield and girth relationship studies on Hevea. J. Rubb. Res. Inst. Malaysia 23(1): 23-31 
NaraYanan, R. and HochaI, Y., (1973): Clonal nursery studies in Hevea II. Relationship between yield and girth. J. Rubb. Res. Inst. Malaysia 23(5): 332-338

NGA, B. H. and Subramaniam, S., (1974): Variation in Hevea brasiliensis I. Yield and girth data of the 1973 hand pollinated seedling. J. Rubb. Res. Inst. Malaysia 2(24): 69-74

PANDEY, D. and BRown. C., (2000): Teak: a global overview. Unasylva 51: $3-13$

RRIC, (1968): Bulletin techniques de l'Institue de Recherche sur le Caoutchuot au Camboge, 1968. Rubber Research Institute of Cambodia (in French)

Samsuddin, Z., TAN, H. and Yoon, P.K., (1987): Correlation studies on photosynthetic rates, girth and yield in Hevea brasiliensis. J. Rubb. Res. Inst. Malaysia 2(1): 64-65

SenghuAT, O., (1981): Correlation between yield, girth and back thickness of RRIM clone trial.. J. Rubb. Res. Inst. Malaysia, 29(1): 1-14

Shorrock, V.M., Tempeton. J.K and Iyer, G. C., (1965): Mineral nutrition, growth and nutrient cycle of Hevea brasiliensis III. The Relationship between girth and shoot dry weight. J. Rubb. Res. Inst. Malaysia 19(1): 85-92

SiM, H. C., (1989): Yield and rubber wood sawn timber. Journal of
Tropical Forest Sciences 2(1): 48-55.6

Suratman, M.N., Bull, G.Q., Leckie, D.G., Lemay, V.M., Marshall, P.L. and Mispan, M.R., (2004): Prediction models for estimating the area, volume, and age of rubber (Hevea brasiliensis) plantations in Malaysia using Land sat TM data. International Forestry Review 6(1): 1-12

Tempeton, J.K., (1968): Growth studies in Hevea brasiliensis I. Growth analysis up to seven years after bud grafting. J. Rubb. Res. Inst. Malaysia, 20(3): 136-146

Tempeton, J.K, (1969): Partition of assimilation. J. Rubb. Res. Inst. Malaysia, 21 (3): 259-263

Trснгт, L., (1981) : L'agriculture au Cambodge. L' Agence de Cooperation culturelle et Technigue, $423 \mathrm{pp}$

WANRaZAli, M., Rosni. M.M. and JOHND. M.Z., (1983): Double entry volume table equations for some RRIM 600 series clones of Hevea brasiliensis. The Malaysian Forester 46(1): 46-59

Westgarth, D. R. and Buttery. B.R., (1965): The effect of planting on the growth, yield and economic exploitation of Hevea brasiliensis Part I. J. Rubb. Res. Inst. Malaysia 19(1): 62-73

(Received 30 September 2006) (Accepted 26 December 2007) 